\title{
PENGARUH MODEL KOOPERATIF TIPE JIGSAW TERHADAP HASIL BELAJAR PKN DI SEKOLAH DASAR
}

\author{
Yulinda $^{1)}$, Reinita $^{2)}$, Mansurdin $^{3)}$ \\ ${ }^{1)}$ Mahasiswa, Universitas Negeri Padang, Indonesia \\ ${ }^{2)}$ Pembimbing 1, Universitas Negeri Padang, Indonesia \\ ${ }^{3}$ Pembimbing 2, Universitas Negeri Padang, Indonesia \\ ${ }^{1)} \underline{\text { lindayulinda@yahoo.com }},{ }^{2)}$ reinita_reinita@yahoo.com,${ }^{3)}$ ajo.mansur@yahoo.co.id
}

\begin{abstract}
Abstrak
Penelitian ini bertujuan untuk mengetahui pengaruh penggunaan model kooperatif tipe Jigsaw terhadap hasil belajar PKn siswa kelas V SDN 10 Sapiran Bukittinggi. Jenis penelitian ini adalah penelitian eksperimen dengan desain quasy eksperimen. Sampel dalam penelitian ini adalah kelas VA dan kelas VB. Hasil perhitungan data penelitian yang digunakan adalah uji-t diperoleh $t_{\text {hitung }}$ $2,7577>t_{\text {tabel }} 2,0128$ pada taraf $\alpha 0,05$. Dengan demikian dapat disimpulkan bahwa terdapat pengaruh yang signifikan dalam penggunaan model kooperatif tipe Jigsaw terhadap hasil belajar PKn siswa kelas V SDN 10 Sapiran Bukittinggi.
\end{abstract}

Kata Kunci: Kooperatif Tipe Jigsaw, Hasil Belajar, PKn

\section{THE INFLUENCE OF USING OF COOPERATIVE JIGSAW TYPE MODEL TOWARD THE RESULT OF PKN IN ELEMENTARY SCHOOL}

\begin{abstract}
The recearch is aimed to know about the influence of using of cooperative jigsaw type model toward the result of PKn student in grade V at SDN 10 sapiran Bukittinggi. The research design of the research is quasy exsperimental design. Sample of the research is class VA and VB. The coubting result of research of data that used is $t$ test founded $t$ count $>\mathrm{t}_{\text {table }} 2, t$-test 2,7577 $>2,0128$ at $\alpha$ level of 0.05. So that, it can be concluded that there is a significant influence in using cooperative model in jigsaw type toward the result of student's PKn study in grade V SDN 10 Sapiran Bukittinggi.
\end{abstract}

Keywords: Cooperative type jigsaw, Learning Outcome, PKn 
PENDAHULUAN

Mata pelajaran Pendidikan

Kewarganegaraan (PKn) merupakan salah satu mata pelajaran yang harus dipelajari mulai dari Sekolah Dasar (SD) sampai perguruan tinggi. Sebagai mana diketahui pembelajaran Pendidikan Kewarganegaraan (PKn) merupakan salah satu mata pelajaran yang memiliki peranan yang sangat penting dalam meningkatkan kualitas pendidikan yang memfokuskan pada pembentukan warga negara yang memahami dan mampu melaksanakan hak-hak dan kewajibannya untuk menjadi warga negara Indonesia yang cerdas, terampil, dan berkarakter sesuai yang diamanatkan oleh Pancasila dan UUD 1945.

Susanto (2016:225) mengemukakan bahwa "PKn adalah mata pelajaran yang digunakan sebagai wahana untuk mengembangkan dan melestarikan nilai luhur dan moral yang berkarakter pada budaya bangsa Indonesia". Mata pelajaran PKn tidak hanya menanamkan konsep pengetahuan semata, tetapi di dalam PKn harus memuat semua aspek pendidikan kewarganegaraan, seperti penanaman sikap dan keterampilan sebagai bekal dalam membentuk warga negara yang demokratis.

Keberhasilan tujuan pembelajaran PKn tentunya sangat dipengaruhi oleh proses pembelajaran yang dilakukan. Walaupun kurikulum pendidikan telah dipersiapkan sedemikian rupa oleh lembaga-lembaga pendidikan, akan tetapi jika proses proses pembelajaran tidak berlangsung dengan tepat dan benar oleh guru dan siswa maka tidak akan memberikan hasil yang baik dan optimal.
Agar

tercapainya

tujuan

pembelajaran $\mathrm{PKn}$, guru harus memiliki kemampuan dan keterampilan dalam melaksanakan proses pembelajaran dengan sebaik mungkin, pembelajaran yang dilakukan guru pun harus kreatif dan tidak boleh menoton sehingga siswa menjadi aktif dan tidak bosan, dan juga kemampuan dan ketepatan guru dalam memilih dan menggunakan model dalam proses pembelajaran

Salah satu model pembelajaran kooperatif yang dapat diterapkan adalah model kooperatif tipe jigsaw. Model pembelajaran tipe jigsaw menuntut siswa untuk lebih aktif dan bertanggung jawab penuh dalam memahami materi pembelajaran. Sebagaimana yang diungkapkan Kurniasih, Imas \& Berlin, sani (2015:24) bahwa "Model pembelajaran jigsaw adalah model pembelajaran kooperatif yang didesain untuk meningkatkan rasa tanggung jawab siswa terhadap pembelajarannya sendiri dan juga pembelajaran orang lain”. Dalam pembelajaran kooperatif tipe jigsaw, pembelajaran dilakukan dengan cara berkelompok dan kelompok-kelompok tersebut disusun secara heterogen. Setiap anggota kelompok diberikan tugas untuk menguasai materi yang berbeda, kemudian masing-masing anggota kelompok bertanggung jawab untuk menyampaikan materi yang telah didapat kepada anggota kelompok lainnya. Artinya setiap anggota kelompok harus ikut berpartisipasi dalam kelompoknya. 
Menurut Lei (dalam Rusman, 2011:218) "Model Kooperatif tipe Jigsaw memiliki kelebihan yakni merupakan salah satu model pembelajaran yang fleksibel, sebab siswa yang terlibat didalam pembelajaran dapat memperoleh hasil belajar yang lebih baik, mempunyai sikap positif terhadap pembelajaran dan melaih siswa untuk saling menghargai perbedaan dan pendapat orang lain". Setiap siswa didalam kelas memiliki latar belakang yang berbedabeda baik dari segi suku, agama, ras, dan juga kemampuan akademik. Model pembelajaran kooperatif memiliki kelebihan dalam mengemban hubungan antara siswa di dalam kelas.

Berdasarkan observasi yang dilakukan peneliti saat pelaksanakan pembelajaran PKn di kelas V SD Negeri 10 Sapiran Bukittinggi semester I tahun pelajaran 2017/2018 pada tanggal 5 dan 6 Juli 2017, guru mengajar menggunakan model pembelajaran konvensional atau pembelajaran yang sering dilakukan guru di kelas seperti metode ceramah dan penugasan, kegiatan pembelajaran yang berlangsung didalam kelas cenderung berpusat kepada guru semata (teacher center), guru kurang melibatkan semua siswa secara aktif dalam pembelajaran. Selain itu guru belum menggunakan model pembelajaran yang bervariasi dan jarang melakukan pembelajaran dengan cara berkelompok.

Hasil lain menunjukkan bahwa sebagian siswa masih bersifat pasif dan kurang tertarik saat proses pelaksanaan pembelajaran PKn berlangsung, siswa lebih banyak duduk dan mendengarkan guru yang sedang menjelaskan materi. Hal ini menyebabkan siswa kurang mempunyai rasa percaya diri, tidak dapat mengemukakan pendapat dan idenya, serta rasa kerjasama dan saling membantu satu sama lain tidak terlihat dikarenakan siswa tidak dibiasakan menyelesaikan tugas bersama dalam kelompok atau berdiskusi dalam pembelajaran. Selain itu, proses pembelajaran masih terpaku pada buku paket tanpa adanya sumber lain dan tidak terlihat dalam pembelajaran guru menggunakan media pembelajaran yang membuat pembelajaran kurang efektif. Serta hanya beberapa siswa yang memiliki tanggung jawab penuh terhadap tugas yang diberikan guru. Kurang aktifnya siswa dalam proses pembelajaran, mengakibatkan hasil belajar siswa pada nilai Ujian Harian Semester 1 Tahun Pelajaran 2017/2018 pada pembelajaran PKn belum sepenuhnya memenuhi Kriteria Ketuntasan Minimum (KKM) yang telah ditetapkan.

Penelitian yang ini bertujuan untuk mengetahui pengaruh model pembelajaran kooperatif tipe Jigsaw terhadap hasil belajar PKn siswa pada materi pentingnya keutuhan Negara Kesatuan Republik Indonesia di kelas V SDN 10 Sapiran Bukittinggi.

\section{METODE PENELITIAN}

Penelitian ini merupakan jenis penelitian kuantitatif. Menurut Sugiyono (2012:34) "Penelitian kuantitatif digunakan apabila peneliti ingin mengetahui pengaruh atau traeatmen tertentu terhadap suatu permasalahan". Metode penelitian yang 
digunakan dalam penelitian ini adalah penelitian eksperimental jenis Quasi Experimental Design dengan menggunakan desain Nonequivalent Control group Design. Menurut Sugiyono (2012:114) “Quasi eksperimental adalah suatu desain penelitian yang memiliki kelompok kontrol tetapi tidak dapat berfungsi sepenuhnya untuk mengontrol variabel-variabel dari luar yang mempengaruhi pelaksanaan eksperimen".

Pada kelompok eksperimen, peneliti memberi perlakuan pembelajaran dengan menggunakan model pembelajaran kooperatif tipe jigsaw, yang bertujuan untuk melihat dampak yang ditimbulkan pada siswa terkait dengan hasil belajar yang akan diperolehnya. Selanjutnya pada kelompok kontrol peneliti melakukan pembelajaran dengan pendekatan konvensional. Kedua kelompok diberikan pretest dan postest dengan menggunakan instrumen tes yang sama.

Dalam penelitian ini akan digunakan desain quasi eksperimen bentuk Nonequivalent Control Group Design, yaitu desain eksperimen quasi yang menggunakan pretest sebelum diberikan perlakuan, dan postest setelah dilakukan perlakuan yang dapat digambarkan sebagai berikut :

Tabel 1. Rancangan Desain Penelitian

\begin{tabular}{|c|c|c|}
\hline O1 & $\mathrm{X}$ & $\mathrm{O} 2$ \\
\hline $\mathrm{O} 3$ & & $\mathrm{O} 4$ \\
\hline
\end{tabular}

Sumber: Sugiyono (2012:112)

Keterangan:

O1: Nilai pre-test pada kelas eksperimen

O2 : Nilai post-test pada kelas eksperimen

O3 : Nilai pre-test pada kelas kontrol
O4 : Nilai post-test pada kelas kontrol

X :Perlakuan pada kelas eksperimen menggunakan model pembelajaran kooperatif tipe jigsaw

Penelitian ini dilaksanakan di SDN 10 Sapiran Bukittinggi pada semester ganjil tahun ajaran 2017/2018. Populasi dalam penelitian ini adalah seluruh siswa kelas $\mathrm{V}$ SDN 10 Sapiran Bukittinggi tahun ajaran 2017/2018. Sampel pada penelitian ini adalah siswa kelas V SD Negeri 10 Sapiran yang terdiri dari dua kelas, kelas VA dan VB yang masing-masingnya berjumlah 24 orang. Teknik pengambilan sampel dilakukan dengan cara Nonprobability sampling yaitu Sampling Jenuh. Menurut Neolaka (2014:97) "Sampling Jenuh adalah sampel yang mewakili jumlah populasi. Biasanya dilakukan jika populasi dianggap kecil atau kurang dari 100. Untuk memilih kelas eksperimen dan kelas kontrol dilakukan secara pengundian. Dari hasil pengundian tersebut, terpilihlah kelas VB sebagai kelas eksperimen dan VA sebagai kelas kontrol.

Instrumen yang akan dipakai dalam penelitian ini yaitu soal-soal tes. Instrumen tes terdiri dari butir-butir soal tes, tipe tes yang digunakan adalah tes objektif. Sebelum melakukan tes terhadap sampel, maka dibuatlah kisi-kisi soal, kemudian dilakukan uji coba untuk mendapatkan soal yang baik yaitu dengan uji validitas, daya beda, indeks kesukaran dan reabilitas. Untuk menentukan valid tidaknya suatu alat ukur dalam penelitian ini digunakan rumus Korelasi Biserial.Untuk menentukan reliabilitas alat 
ukur dalam penelitian ini menggunakan rumus KR. 20 (Kuder Richardson).Adapun teknik analisis data yang digunakan dalam penelitian ini adalah: uji normalitas, uji homogenitas, dan uji t (t-test).

\section{HASIL DAN PEMBAHASAN}

\section{Hasil}

1. Deskripsi Data Pretest dan Posttest Kelas Eksperimen dan Kelas Kontrol

Hasil yang diperoleh pada pretest dan posttest dari kelas eksperimen dan kelas kontrol penelitian ini disajikan dalam tabel berikut ini:

Tabel 1 Data Pretest dan Posttest Kelas Eksperimen dan Kelas Kontrol

\begin{tabular}{|l|c|c|c|c|}
\hline \multirow{2}{*}{} & \multicolumn{2}{|c|}{ Kelas Eksperimen } & \multicolumn{2}{c|}{ Kelas Kontrol } \\
\cline { 2 - 5 } & $\begin{array}{c}\text { Hasil } \\
\text { pretest }\end{array}$ & $\begin{array}{c}\text { Hasil } \\
\text { postest }\end{array}$ & $\begin{array}{c}\text { Hasil } \\
\text { pretest }\end{array}$ & $\begin{array}{c}\text { Hasil } \\
\text { postest }\end{array}$ \\
\hline $\mathrm{N}$ & 24 & 24 & 24 & 24 \\
\hline $\begin{array}{l}\text { Nilai } \\
\text { maksim } \\
\text { un }\end{array}$ & 80 & 100 & 72 & 92 \\
\hline $\begin{array}{l}\text { Nilai } \\
\text { minimu } \\
\text { m }\end{array}$ & 40 & 60 & 40 & 60 \\
\hline $\begin{array}{l}\text { Rata- } \\
\text { rata }\end{array}$ & 55,66 & 85,33 & 56,83 & 76,5 \\
\hline
\end{tabular}

Berdasarkan tabel 1, dapat dilihat bahwa hasil pretest pada kelas eksperimen nilai tertinggi 80 dan terendah 40 dan nilai rata-rata sebesar 55,66. Sedangkan pada kelas kontrol nilai tertinggi 72 dan terendah 40 dan nilai rata-rata sebesar 56,83 . Dengan demikian rata-rata pretest kelas kontrol lebih tinggi dari pada ratarata pretest kelas eksperimen sebesar 1,17. Namun setelah dilakukan pembelajaran pada kelas eksperimen dengan menggunakan model Kooperatif Tipe Jigsaw, dan pada kelas kontrol dilakukan pembelajaran dengan model konvensional, diketahui bahwa hasil posttest pada kelas eksperimen nilai tertinggi 100 dan terendah 60 dan nilai rata-rata 85,33, sedangkan hasil posttest pada kelas kontrol nilai tertinggi 92 dan terendah 60 dan rata-rata 76,5. Dengan demikian ratarata posttest kelas kontrol lebih tinggi dari pada rata-rata posttest kelas eksperimen sebesar 8,83 .

2. Pengujian Prasarat Analisis dan Pengujian Hipotesis

a. Uji Normalitas

Uji normalitas dilakukan untuk mengetahui apakah data yang dipeoleh berdistribusi normal atau tidak. Uji normalitas dalam penelitian ini menggunakan uji Liliefors dengan berbantu Microsoft Excel 2007 dengan taraf signifikansi $5 \%$ atau $\alpha=0,05$.

1) Normalitas pretest kelas eksperimen dan kelas kontrol

Hasil uji normalitas pretest pada kelas eksperimen dan kelas kontrol dalam penelitian ini disajikan pada tabel berikut:

Tabel 2. Hasil Uji Normalitas Pretest Kelas Eksperimen dan Kontrol

\begin{tabular}{|c|l|c|c|c|c|}
\hline $\begin{array}{c}\mathrm{N} \\
\mathrm{o}\end{array}$ & Kelas & $\mathrm{N}$ & Lhitung & $\begin{array}{c}\text { Ltabel } \\
\alpha 0,05\end{array}$ & Kesimpulan \\
\hline 1 & $\begin{array}{l}\text { Eksperi } \\
\text { men }\end{array}$ & 24 & 0,1305 & 0,173 & Data Normal \\
\hline 2 & Kontrol & 24 & 0,1602 & 0,173 & Data Normal \\
\hline
\end{tabular}

Berdasarkan tabel 2, diketahui Lhitung kelas eksperimen sebesar 0,1505 dan Lhitung kelas kontrol sebesar 0,1602 dengan jumlah sampel masing-masing 24. Pada taraf signifikansi $\alpha=0,05$ 
didapat nilai Ltabel sebesar 0,173.

Sehingga pada kelas eksperimen diperoleh Lhitung < Ltabel, $(0,1305<0,173)$, dan pada kelas kontrol juga diperoleh Lhitung < Ltabel $\quad(0,1602<0,173)$. Maka dengan demikian, dapat disimpulkan bahwa data pada kedua kelas berdistribusi normal.

2) Normalitas posttest kelas eksperimen dan kelas kontrol Hasil uji normalitas posttest

kelas eksperimen dan kelas kontrol dalam penelitian ini disajikan pada tabel berikut:

Tabel 3. Hasil Uji Normalitas Posttest Kelas Eksperimen dan Kontrol

\begin{tabular}{|c|l|c|c|c|c|}
\hline & Kelas & $\mathrm{N}$ & Lhitung & $\begin{array}{l}\text { Ltabel } \\
\alpha 0,05\end{array}$ & Kesimpulan \\
\hline 1 & $\begin{array}{l}\text { Eksperi } \\
\text { men }\end{array}$ & 24 & 0,1006 & 0,173 & Data Normal \\
\hline 2 & Kontrol & 24 & 0,1198 & 0,173 & Data Normal \\
\hline
\end{tabular}

Berdasarkan tabel 3, diketahui Lhitung kelas eksperimen sebesar 0,1006 dan Lhitung kelas kontrol sebesar 0,1198 dengan jumlah sampel masing-masing 24 . Pada taraf signifikansi $\alpha=0,05$ didapat nilai Ltabel sebesar 0,173 . Pada kelas eksperimen diperoleh Lhitung < Ltabel, $(0,1006<0,173)$, dan pada kelas kontrol diperoleh Lhitung < Ltabel $(0,1198<0,173)$. Dengan demikian, dapat disimpulkan bahwa data pada kedua kelas berdistribusi normal.

b. Uji Homogenitas

Uji homogenitas dalam penelitian ini dilakukan untuk mengetahui apakah data untuk kelas eksperimen dan kelas kontrol memiliki varian yang homogen atau tidak. Uji homogenitas dalam penelitian ini dilakukan dengan menggunakan uji-F berbantu Microsoft Excel 2007 dengan taraf signifikansi $5 \%$ atau $\alpha=0,05$.

1) Homogenitas pretest kelas eksperimen dan kelas kontrol

Hasil uji homogenitas pretest kelas eksperimen dan kelas kontrol dalam penelitian ini adalah sebagai berikut:

Tabel . Hasil Uji Homogenitas Pretest Kelas Eksperimen dan Kontrol

\begin{tabular}{|c|l|c|c|c|c|c|}
\hline $\begin{array}{c}\text { N } \\
\text { o }\end{array}$ & Kelas & $\mathrm{N}$ & Variansi & Fhitung & Ftabel & $\begin{array}{c}\text { Kesimp } \\
\text { ulan }\end{array}$ \\
\cline { 1 - 3 } 1 & $\begin{array}{l}\text { Eksperi } \\
\text { men }\end{array}$ & 24 & $\begin{array}{c}139,014 \\
5\end{array}$ & 1,5617 & $\begin{array}{c}2,014 \\
4\end{array}$ & $\begin{array}{c}\text { Varian } \\
\text { Homog } \\
\text { en }\end{array}$ \\
\hline 2 & Kontrol & 24 & 89,0145 & & & \\
\hline
\end{tabular}

Berdasarkan tabel 4, diketahui Fhitung kelas eksperimen dan kelas kontrol sebesar 1,5617 dengan jumlah sampel masing-masing 24. Pada taraf signifikansi $\alpha=0,05$ didapat Ftabel 2,0144. Sehingga diperoleh Fhitung < Ftabel, yakni $(1,5617$ < 2,0144). Jadi, dapat disimpulkan bahwa data pada kelas eksperimen dan kelas kontrol memiliki varian yang homogen.

2) Homogenitas posttest kelas eksperimen dan kelas kontrol

Hasil uji homogenitas posttest kelas eksperimen dan kelas kontrol dalam penelitian ini adalah sebagai berikut: 
Tabel 5. Hasil Uji Homogenitas Posttest

Kelas Eksperimen dan Kontrol

\begin{tabular}{|c|l|c|c|c|c|c|}
\hline $\begin{array}{c}\mathrm{N} \\
\mathrm{o}\end{array}$ & Kelas & $\mathrm{N}$ & Variansi & Fhitung & Ftabel & $\begin{array}{c}\text { Kesimp } \\
\text { ulan }\end{array}$ \\
\cline { 1 - 4 } 1 & $\begin{array}{l}\text { Eksperi } \\
\text { men }\end{array}$ & 24 & $\begin{array}{c}131,710 \\
1\end{array}$ & \multirow{2}{*}{1,1501} & $\begin{array}{c}2,014 \\
4\end{array}$ & $\begin{array}{c}\text { Varian } \\
\text { Homoge } \\
\mathrm{n}\end{array}$ \\
\cline { 1 - 4 } 2 & Kontrol & 24 & $\begin{array}{c}114,521 \\
7\end{array}$ & & & \\
\hline
\end{tabular}

Berdasarkan tabel 5, diketahui

Fhitung kelas eksperimen dan kelas kontrol sebesar 1,1501 dengan jumlah sampel masing-masing 24. Pada taraf signifikansi $\alpha=0,05$ didapat Ftabel 2,0144. Sehingga diperoleh Fhitung < Ftabel, yakni $(1,1501<2,0144)$. Dan dapat disimpulkan bahwa data pada kelas eksperimen dan kelas kontrol memiliki varian yang homogen.

c. Uji Hipotesis

Berdasarkan uji prasyarat analisis data posttest untuk kelas eksperimen dan kelas kontrol diketahui bahwakedua kelas berdistribusi normal dan memiliki varians yang homogen. Dengan kata lain, dapat dilakukan pengujian hipotesis dengan menggunakan uji $\mathrm{t}$ independent atau uji t sampel bebas dengan cara melakukan uji dua pihak.

Hasil perhitungan nilai posttest dengan menggunakan uji $\mathrm{t}$ disajikan pada tabel berikut:

Tabel 6 Hasil Uji T data Posttest Kelas Eksperimen dan Kelas Kontrol

\begin{tabular}{|c|l|c|c|c|c|c|}
\hline $\begin{array}{c}\text { N } \\
\text { o }\end{array}$ & Kelas & N & Mean & $\begin{array}{c}\text { Thitu } \\
\mathrm{ng}\end{array}$ & $\begin{array}{c}\text { Ttabel } \alpha \\
0,05 / 2\end{array}$ & $\begin{array}{c}\text { Kesimpula } \\
\mathrm{n}\end{array}$ \\
\cline { 1 - 4 } 1 & $\begin{array}{l}\text { Eksperi } \\
\text { men }\end{array}$ & 24 & 85,33 & $\begin{array}{c}2,757 \\
7\end{array}$ & 2,0128 & Ho ditolak. \\
\cline { 1 - 3 } 2 & Kontrol & 24 & 76,5 & & & \\
\hline
\end{tabular}

Tabel 6 menunjukkan perolehan nilai $t$ hitung sebesar 2,7577 dan $t$ tabel
2,0128 pada taraf signifikasi $\alpha / 2$ atau 0,05/2. Karena 2,7577 > 2,0128 maka Ho ditolak, dan Ha diterima. Sehingga dapat disimpulkan bahwa ada pengaruh penggunaan model Kooperatif Tipe Jigsaw pada Pembelajaran PKn di kelas V SDN 10 Sapiran Bukittinggi.

\section{Pembahasan}

Penelitian ini dilakukan untuk mengetahui pengaruh penggunaan model kooperatif tipe jigsaw terhadap hasil belajar PKn siswa kelas $\mathrm{V}$ SDN 10 Sapiran Bukittinggi. Untuk mengetahui pengetahuan awal kedua kelas, maka terlebih dahulu dilakukan tes awal atau pretest. Dari hasil uji normalitas dan homogenitas yang dilakukan terhadap hasil belajar siswa pada nilai pretest menunjukkan bahwa siswa kelas VA dan siswa kelas VB pada SDN 10 Sapiran memiliki sebaran data yang berdistribusi normal dan varian yang homogen.

Kelas eksperimen pada penelitian ini diberi perlakuan dengan menggunakan model kooperatif tipe Jigsaw sedangkan kelas kontrol dilakukan pembelajaran dengan model konvensional. Selanjutnya kedua kelas dilakukan postest untuk memperoleh data yang akan digunakan untuk pengujian hipotesis. Berdasarkan hasil posttest diperoleh nilai terbesar untuk kelas eksperimen sebesar 100 dan kelas kontrol sebesar 92. Nilai ratarata untuk kelas eksprimen sebesar 85,33 sedangkan kelas kontrol sebesar 76,5

Dari hasil uji hipotesis posttest yang dilakukan dengan menggunakan uji t, didapatkan thitung>ttabel $(2,7577>2,012)$. 
Dengan demikian Ho ditolak dan Ha diterima. Artinya terdapat pengaruh yang signifikan dalam penggunaan model kooperatif tipe jigsaw terhadap hasil belajar PKn siswa kelas V SDN 10 Sapiran Bukittinggi. Dari hasil data posttest siswa kelas eksperimen dan kelas kontrol, diketahui bahwa hasil belajar siswa kedua kelompok penelitian ini menunjukkan adanya perbedaan yang signifikan, dengan rata-rata nilai posttest kelas eksperimen lebih tinggi sebesar 8,83 dibandingkan dengan rata-rata nilai postest kelas kontrol.

Berdasarkan hasil penelitian dan pembahasan diatas, maka dapat dinyatakan bahwa pembelajaran dengan menggunakan model kooperatif tipe jigsaw merupakan solusi yang tepat untuk mengembangkan pembelajaran dan dapat berpengaruh terhadap hasil belajar PKn siswa dalam pembelajaran PKn kelas V Sekolah Dasar.

\section{SIMPULAN}

Berdasarkan hasil penelitian quasi eksperiment yang telah dilaksanakan pada pembelajaran PKn di kelas V Sekolah Dasar Negeri 10 Sapiran diperoleh nilai rata-rata posttest kelas eksperimen sebesar 85,33 dan kelas kontrol sebesar 76,5. Hal ini menunjukkan bahwa kelas eksperimen yang melakukan pembelajaran dengan model Kooperatif Tipe Jigsaw memperoleh nilai rata-rata hasil belajar yang lebih baik daripada kelas kontrol yang melakukan pembelajaran dengan model konvensional.

Dari hasil uji hipotesis dengan menggunakan uji t pada taraf signifikansi 5\% atau $\alpha=0,05$, didapat thitung sebesar 2,7577 dan ttabel sebesar 2,0128. Maka diperoleh thitung > ttabel $(2,7577>2,0128)$, sehingga Ho ditolak. Dengan demikian dapat disimpulkan bahwa terdapat pengaruh penggunaan model Kooperatif Tipe Jigsaw terhadap hasil belajar PKn siswa kelas V SDN 10 Sapiran Bukittinggi.

Berdasarkan kesimpulan yang telah diperoleh dalam penelitian ini diajukan beberapa saran untuk dipertimbangkan, yaitu 1) Bagi guru agar dapat menerapkan model pembelajaran Kooperatif tipe Jigsaw sabagai salah satu variasi model mengajar mamapu memberikan pengaruh positif terhadap hasil belajar. 2) Model pembelajaran jigsaw dapat diterapkan dan mampu memberikan pengaruh positif terhadap hasil belajar siswa, namun harus dengan pemahaman guru tentang langkahlangkah model jigsaw. 3) Peneliti lain, kepada peneliti berikutnya diharapkan dapat melaksanakan penelitian ini ke sekolah dasar lainnya dengan materi dan kelas yang berbeda.

\section{DAFTAR RUJUKAN}

Kurniasih, Imas \& Sani, Berlin. 2015. Ragam Pengembangan Model Pembelajaran Untuk Peningkatan Profesionalitas Guru. Yogyakarta: Kata Pena

Neolaka, Amos. 2014. Metode Penelitian dan Statistik. Bandung: Remaja Rosdakarya

Rusman. 2014. Model-Model Pembelajaran Mengembangkan Profesionalisme Guru. Jakarta: Rajawali Pers 
Sugiyono. 2012. Metode Penelitian

Pendidikan (Pendekatan kuantitatif

Kualitatif dan $R \& B$ ). Bandung:

Alfabeta
Susanto, Ahmad. 2016. Teori Belajar dan Pembelajaran di Sekolah Dasar.

Jakarta: Kencana 